\title{
Characterization of the testicular regeneration potential in premature cockerels
}

\author{
Po-Liang CHENG ${ }^{1,2)}$, Hui-Ru WU ${ }^{2)}$, Cheng-Yan $\mathrm{LI}^{1,2)}$, Chih-Feng $\mathrm{CHEN}^{1,3)}$ and \\ Hsu-Chen CHENG ${ }^{1,2)}$ \\ ${ }^{1)}$ Center for integrative Evolutionary Galliform Genomics Research (iEGG Center), National Chung Hsing University, \\ Taichung City 402, Taiwan \\ ${ }^{2)}$ Department of Life Sciences, National Chung Hsing University, Taichung City 402, Taiwan \\ ${ }^{3)}$ Department of Animal Sciences, National Chung Hsing University, Taichung City 402, Taiwan \\ \# Present: Taiwan International Patent \& Law Office, Taipei City 104, Taiwan
}

\begin{abstract}
Previous studies have shown that grafted neonatal chicken testicular tissue can develop and produce functional sperm; however, it was unclear whether regenerative processes or proportional growth caused the re-appearance of spermatogenic tissue. We dissociated testicular tissues, performed subcutaneous auto-transplantation of the re-aggregated cells to castrated cockerels, and monitored the post-surgery development of these transplanted aggregates. We found that these transplanted cell aggregates experienced compensatory growth in the form of a 300 -fold increase in size, rather than the 30-fold increase observed in normal testis development. Further, these dissociated testicular cell aggregates restored seminiferous tubule structure and were able to produce testosterone and motile sperm. Therefore, we concluded that the dissociated testicular cells from 11-week-old cockerels retained a strong regenerative potential, as they exhibited compensatory growth, restored destroyed structure, and sustained spermatogenesis.
\end{abstract}

Key words: Auto-transplantation, Cockerel, Regeneration potential, Spermatogenesis, Testis

(J. Reprod. Dev. 63: 563-570, 2017)

O rgan regeneration is the ultimate goal of regenerative medicine. Regeneration is commonly defined as the replacement of lost body parts and the restoration of mass and function [1]. The regeneration of amputated salamander limbs is a popular model for the study of organ regeneration, as its regeneration includes de-differentiation, stem cell proliferation, the re-acquisition of position information, differentiation, maturation, and size control. Although the regeneration ability is much more limited in higher vertebrates, some regeneration capacity is still in several organs. For example, the nail and digit tip are able to fully regenerate after removal in mice, but further amputation did not lead to regeneration as the stem cells associated with the nails were also removed [2].

For most organs, their development and differentiation is a continuous process. However, gonad development is separated into two phases. During embryonic development in mammals, the bi-potential genital ridges develop into testes or ovaries depending on the expression of male or female sex determination genes. In avians, somatic cells possess an inherent sex identity and sexual differentiation is substantially cell autonomous [3]. Furthermore, the germ cells in embryonic ovaries enter meiosis and arrest at dictyate stage, whereas

Received: June 22, 2017

Accepted: August 21, 2017

Published online in J-STAGE: September 8, 2017

(C)2017 by the Society for Reproduction and Development

Correspondence: H-C Cheng (e-mail: hcheng@dragon.nchu.edu.tw)

This is an open-access article distributed under the terms of the Creative Commons Attribution Non-Commercial No Derivatives (by-nc-nd) License. (CC-BY-NC-ND 4.0: https://creativecommons.org/licenses/by-nc-nd/4.0/) the germ cells in testes do not undergo meiosis and remain as gonocytes [4]. The germ cells in both sexes resume differentiation in response to reproductive hormone stimulation as the individual enters puberty [5]. The proper structural arrangement and functions of somatic cells are necessary for robust spermatogenesis. The main structure of testes are seminiferous tubules and interstitial cells, which comprise three major cell types: germ cells, Sertoli cells, and Leydig cells. Germ cells undergo meiosis to produce haploid sperm, Sertoli cells harbor germline stem cells and regulate spermatogenesis, and the major function of Leydig cells in the interstitial space is steroid hormone synthesis. The delicate structure and cross-talk among these three cell types is important for the function of each cell type in the testis.

The testis is not only responsible for spermatogenesis, but also for sex hormone production in animals. Several attempts using zebrafish, mice, and pigs for the characterization of testis regeneration revealed limited spermatogenic or steroidogenic functions, except in newborn animals [6-8]. Similarly, studies by Song and Silversides (2007) [9] reported that hetero-transplanted testicular slices from a newly hatched chick into a recipient chick's abdomen were able to grow and produce functional sperm that generated donor-derived progeny, which suggested that chicken testes have a strong regenerative potential. Therefore, we attempted to establish the chicken as an animal model to allow the characterization of the factors that are essential for testis regeneration and preserve both the spermatogenic and steroid hormone-producing capabilities.

Additionally, although previous studies have shown the regrowth of neonatal testicular tissues and the production of functional sperm [9], the growth of the transplanted testicular tissues was reflected 
through the proportional growth in the adolescent development and the compensatory growth from the testicular regeneration was unclear. Additionally, the regeneration potential decreases with organ maturation; hence, the use of tissues from newly hatched chicks restricted its application to regeneration studies in adults $[10,11]$.

\section{Materials and Methods}

\section{Ethical statement on animal care}

All animal experiments in this report were approved by the Institutional Animal Care and Use Committee (IACUC) of National Chung Hsing University under the Animal protocol \#99-87 (Molecular mechanisms of gonad regeneration in avian species). One-day-old White Leghorn male chickens were obtained from Kingdom Poultry Farm and house in an animal facility with a 16:8-h light-dark cycle.

\section{Testicular tissue auto-transplantation}

For testicular tissue auto-transplantation, the cockerels of the desired age were fasted for 1 day and anesthetized with Zoletil 50 (Virbac, Fort Worth, Texas, United States). For each male chicken, both testes were excised and the tunica albuginea membrane was manually removed to expose the inner testicular tissue. Each of the testicular tissues were then passed through an 18-G needle to destroy the tubular structure and to dissociate cells. Ten microliters of these processed tissues was diluted with PBS and the level of dissociation was verified under a microscope. Subsequently, one microliter of dissociated cell aggregate was introduced ectopically to the subcutaneous space on the torso flanking region beneath the wing of the cockerel from which it was removed. After surgery, we collected a blood sample and performed weekly measurements of the size of the transplanted tissues. We applied dental Cavex CA37 (Cavex Holland BV, Haarlem, The Netherlands) over the regenerated tissues to take molds of their shapes. After the Cavex cured, we filled the cavities with water and measured the weights of water added into each mold to estimate the regenerated tissue volume. The weights of each regenerated testicular tissues were obtained through the multiplication of the regenerated tissue volumes by the density of chicken testis $(1.05 \mathrm{~g} / \mathrm{cc},[12])$. To establish a standard growth curve of normal developing testes, we sacrificed the male chickens weekly and collected their testes to measure their size and weight.

\section{Histological examination}

The collected testicular tissues were fixed with $4 \%$ paraformaldehyde or Bouin's solution, embedded in paraffin, and sliced into sections of 5- $\mu \mathrm{m}$ thickness. Immunohistochemical analyses were performed in accordance with previously described procedures [13]. The antibodies used were: proliferating cell nuclear antigen, PCNA (Abcam ab29, Cambridge, MA, USA, 1:1000); a germ cell marker: chicken-vasa homolog, CVH (a gift from Dr Bertrand Pain's lab, 1:1000); a Leydig cell marker: cholesterol side-chain cleavage enzyme, P450scc/SCC (a gift from Dr Bon-Chu Chung's lab, 1:200); a Sertoli cell marker: Wilms tumor 1, WT1 (Santa Cruz sc-192, Santa Cruz Biotechnology, Dallas, Texas, USA, 1:200); smooth muscle actin, SMA (SIGMA C6198, Sigma-Aldrich, St. Louis, MO, USA, 1:200); and a meiosis marker: synaptonemal complex protein 3, SYCP3 (Novus NB300-232, NOVUS INTERNATIONAL, Saint Charles,
Missouri, USA, 1:1000). We generated two polyclonal antibodies against undifferentiated spermatogonia (GDNF family receptor $\alpha 1$, GFR $\alpha 1:$ KNTGS ETTNN EIPTH NDSPC) and differentiated spermatogonia (c-kit, NP_989692.1 668a.a.-940a.a.) and analyzed their specificity on extracted testicular proteins and mature chicken testis sections. The samples were imaged with an Olympus IX71 microscope.

\section{Plasma testosterone analysis}

Two microliters of whole blood sample was centrifuged at 1450 $\times g$ at $4^{\circ} \mathrm{C}$ and the upper layer of plasma was recovered for further analysis. The plasma testosterone concentration was measured with BECKMAN COULTER Access Testosterone Reagent (Beckman Coulter, South Kraemer Boulevard, Brea, CA, USA). Owing to the low plasma testosterone concentration and possible fluctuations of the concentration, many of the collected samples did not give a significant response to the measured testosterone concentration. Therefore, we used rooster comb growth and the appearance of spermatogenesis, two testosterone-dependent developmental processes, as alternative biological indicators for testosterone production.

\section{Statistical analysis}

All samples were collected with a minimum of three repeats $(n \geq 3)$. For histological examinations, a single representative image was selected from a minimum of three independent experiments. Significant differences in the data were estimated by Student's $t$-test and the relevant graphs were plotted by Sigmaplot (Systat Software, San Jose, CA).

\section{Results}

Chicken testis could grow back after auto-transplantation with compensatory growth

To confirm whether the testicular tissues were regrown through a regeneration process, we developed an auto-transplantation strategy with the removal of both testes from the male chickens and the reintroduction of the dissociated testicular cells to allow easy monitoring of the transplant size. First, we intended to distinguish whether the regrown testicular tissues were a result of proportional growth that reflected adolescent proliferation or compensatory growth, we designed an animal experiment scheme (Fig. 1A) and compared the volume increase in the control testes and transplanted testicular tissue. The control chicken testis size increase was measured weekly from week 1 to week 20 (Fig. 1B).

As the regrown testicular tissues were of irregular shape, we made a plaster mold of transplanted tissue with dental alginate and the water volume required to fill the alginate mold was used to estimate the volume of the transplanted tissue. To continuously monitor the size change of auto-transplanted testicular tissues from week 11, we cast a mold on the site of tissue introduction; the tissue thickening began at week 15, and the size increased throughout the experiment period (Fig. 1C) until we terminated their growth at week 20 and collected the transplant samples for further analysis. The analysis of the growth trends, shown in Fig. 1D, indicated that the control chicken testes started to grow rapidly from week 11 and entered a growth plateau phase after week 18. 
A
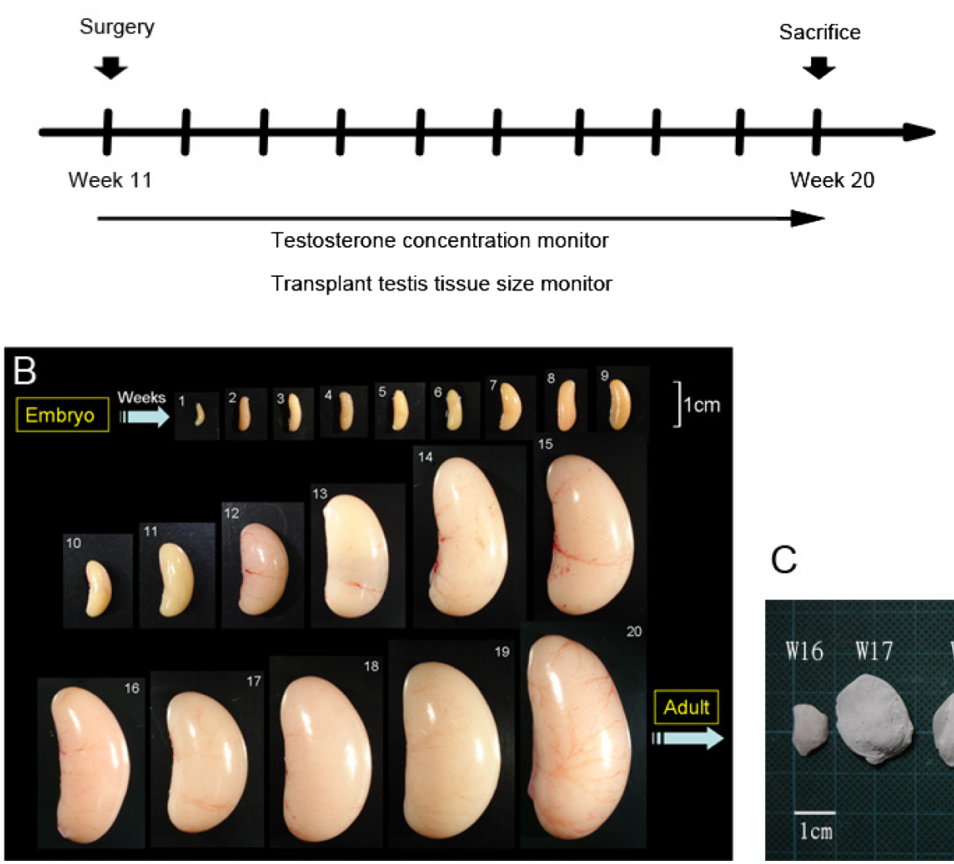

D

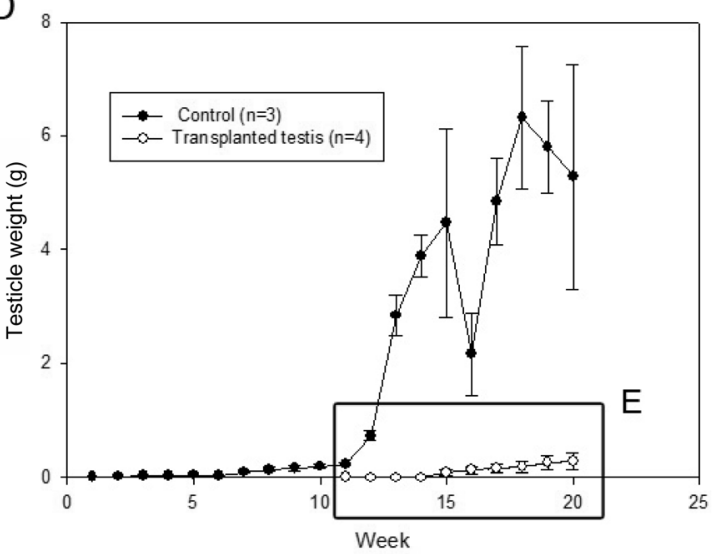

E

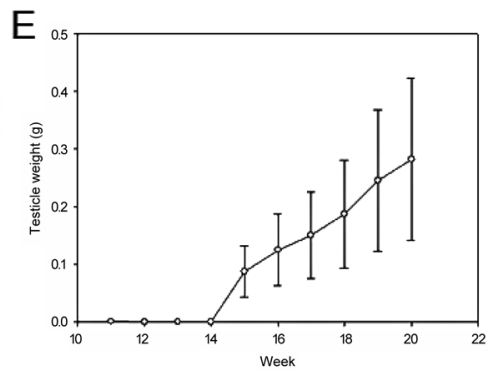

Fig. 1. Chicken testis can grow back after auto-transplantation. (A) Experimental scheme of animal experiment. (B) Testis developmental progression in control chicken. (C) Plaster replicates collection of growing transplanted testicular tissue from one rooster. (D) Weekly testes weight change of control and transplanted chicken, and the weight increase of regenerated testes were enlarged and shown in (E).

Although the sizes of transplanted tissues were only $1 / 20$ of control testes at week 20, it had a higher relative growth than that of the control testis (Fig. 2A). This indicated that the transplanted testes grew back not through proportional growth, but through compensatory growth. To examine the contribution of different gonadal cell types to this compensatory growth, we compared the distribution and number of PCNA-positive cells (a marker of proliferation) between the control and transplant tissues at week 20 . We found that the number of proliferating cells in the transplanted testes was similar to that in the control testes in week 20 (Fig. 2B, C), but the interstitial spaces were larger and contained more proliferating cells than in the control (Fig. 2G, H). Furthermore, we found proliferating Sertoli cells in the transplanted tissue (Fig. 2D-F), which are characteristically observed between weeks 7 and 9 in normally developing testes [14]. Therefore, we believe that the size of transplants at week 20 did not represent the culmination of the compensatory growth; time permitting, the transplanted testis tissues may grow to their full original size.

The dissociated testicular cells resumed their original positions

To further understand how the regrown testicular tissues increased in size and also reconstructed testicular structures from the dissociated cells, we performed immunohistochemical analyses to verify whether the major cell types of the testis had developed and resumed their positions. As the most distinctive structures of the testis are the seminiferous tubules, we examined the intactness of tubules by immunohistochemical staining of smooth muscle actin (SMA).
In the transplanted tissues, we found that the SMA-positive cells formed continuous circles (Fig. 3A, B) and provided a structural base for other somatic cells and germ cells to grow and expand within them. In the space enclosed by SMA, we detected many CVH positive cells and some distinct peripheral WT1 positive cells, which resembled the distribution found within normal tubules (Fig. 3E-H). Furthermore, the SCC-positive cells were found in the interstitial spaces, which suggested that the Leydig cells also resumed their original positions (Fig. 3I, J).

\section{The subcutaneous transplanted testicular tissues proceeded to} spermatogenesis and testosterone production

As the immunohistochemical staining of the major cell types of the testis indicated that these cells had rebuilt tubular structures and resumed their positions, we were motivated to confirm whether the cells had regained their biological functions. To determine whether the germ cells could complete spermatogenesis, we examined different spermatogenesis stages in the transplanted testis. Three important spermatogenic stages were examined by specific antibodies. GFR $\alpha 1$-positive cells represent a subpopulation of undifferentiated spermatogonia, which includes germline stem cells on the basement membrane of seminiferous tubules [15-18]. We detected GFR $\alpha 1$ positive cells in the peripheral region of seminiferous tubules in both the control and transplanted testis (Fig. 4A, B). The next stage of spermatogenesis is the differentiation of spermatogonia, which is represented by the expression of c-kit, which will differentiate into 

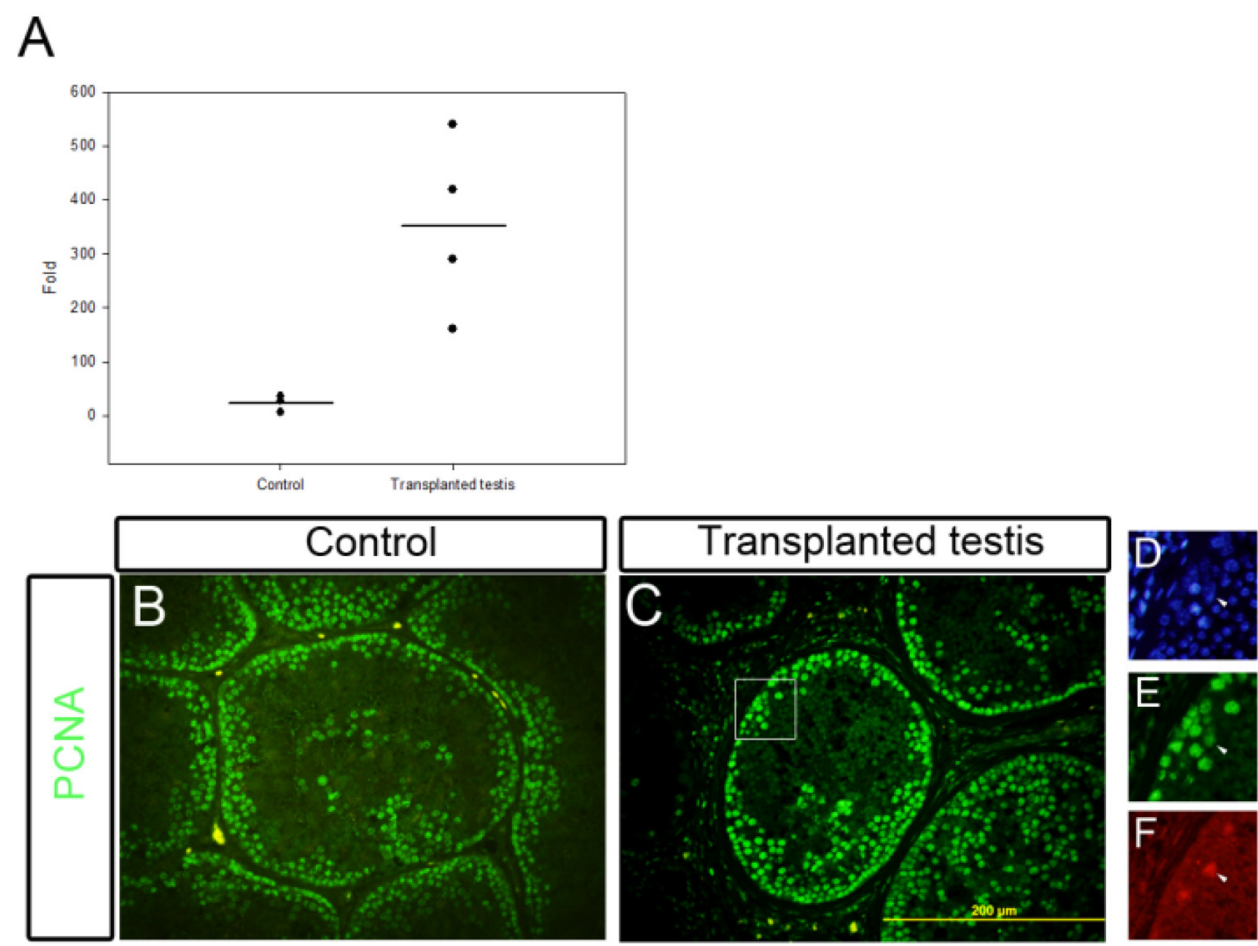

G

$\mathrm{H}$
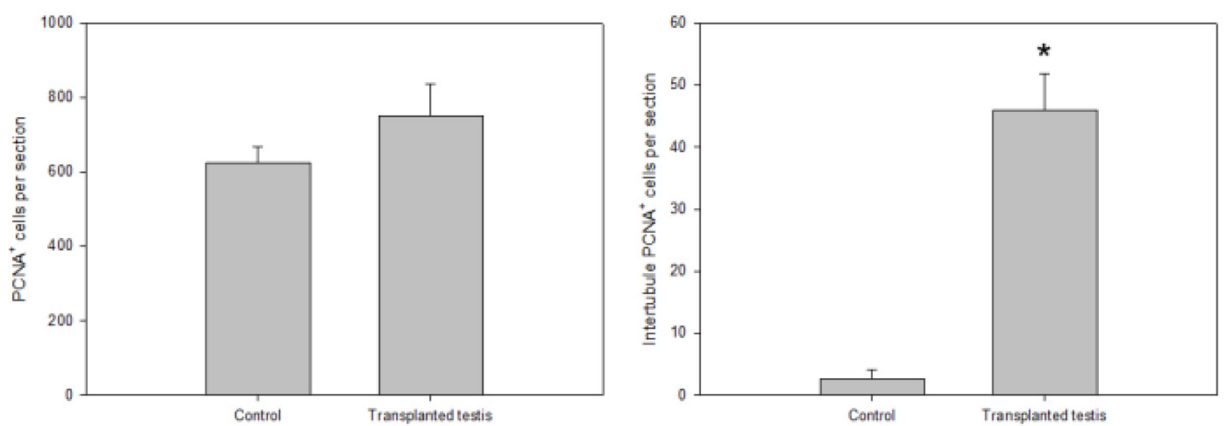

Fig. 2. Auto-transplanted testis tissue can grow back through a compensatory manner. (A) Transplanted testicular tissues have larger weight increasing fold than control testis. (B, C) Both transplanted and control testes showed active proliferation inside tubules at week 20. (D, E, F) Proliferating Sertoli cells (PCNA+, WT1+) were found in transplanted testicular at 20-week-old. (G, H) Proliferation analysis indicates both tissues have comparable PCNA positive cells per section, but the transplanted testicular tissues showed many more PCNA positive cells in interstitial space (possibly Leydig cells).

type B spermatogonia [16, 19, 20]. The c-kit signals were detected in clustered cells, distributed peripherally, and some extended inward to the center of each tubule (Fig. 4C, D). SYCP3 appears as cells form synapsis complexes and is used as a marker of meiosis [21], therefore we used SYCP3 to determine whether meiosis was initiated in our samples. SYCP3-positive cells were detected inside the seminiferous tubules of both the control and transplanted testes (Fig. $4 \mathrm{E}, \mathrm{F})$. Elongated nuclei were observed in the lumen of regrown testes, suggesting the germ cells has completed spermatogenesis; therefore, we examined the mobility of sperm from the autopsied samples of regrown testes and confirmed the existence of motile sperm (Supplementary Movie). From these data, we demonstrated that after auto-transplantation, the dissociated germ cells might be germline stem cells and that Sertoli cells had resumed their intratubular positions and proceeded to spermatogenesis as the transplants matured.

In addition to sperm production, the testis is also an endocrine organ. Leydig cells, which reside in the interstitial spaces, are responsible for testosterone production. To verify whether 11-week-old immature Leydig cells continued to develop to testosterone synthesis, we collected plasma samples weekly and analyzed the testosterone concentration after transplantation by using ELISA. After the age of 12 weeks old, plasma testosterone became detectable in control chicken; however, the testosterone concentration remained undetectable by ELISA kit even in 20-week-old males in the transplant group (Fig. $5 \mathrm{~A})$. As comb size reflects testosterone activity in rooster [22], we used the development of the comb as an indicator of testosterone 


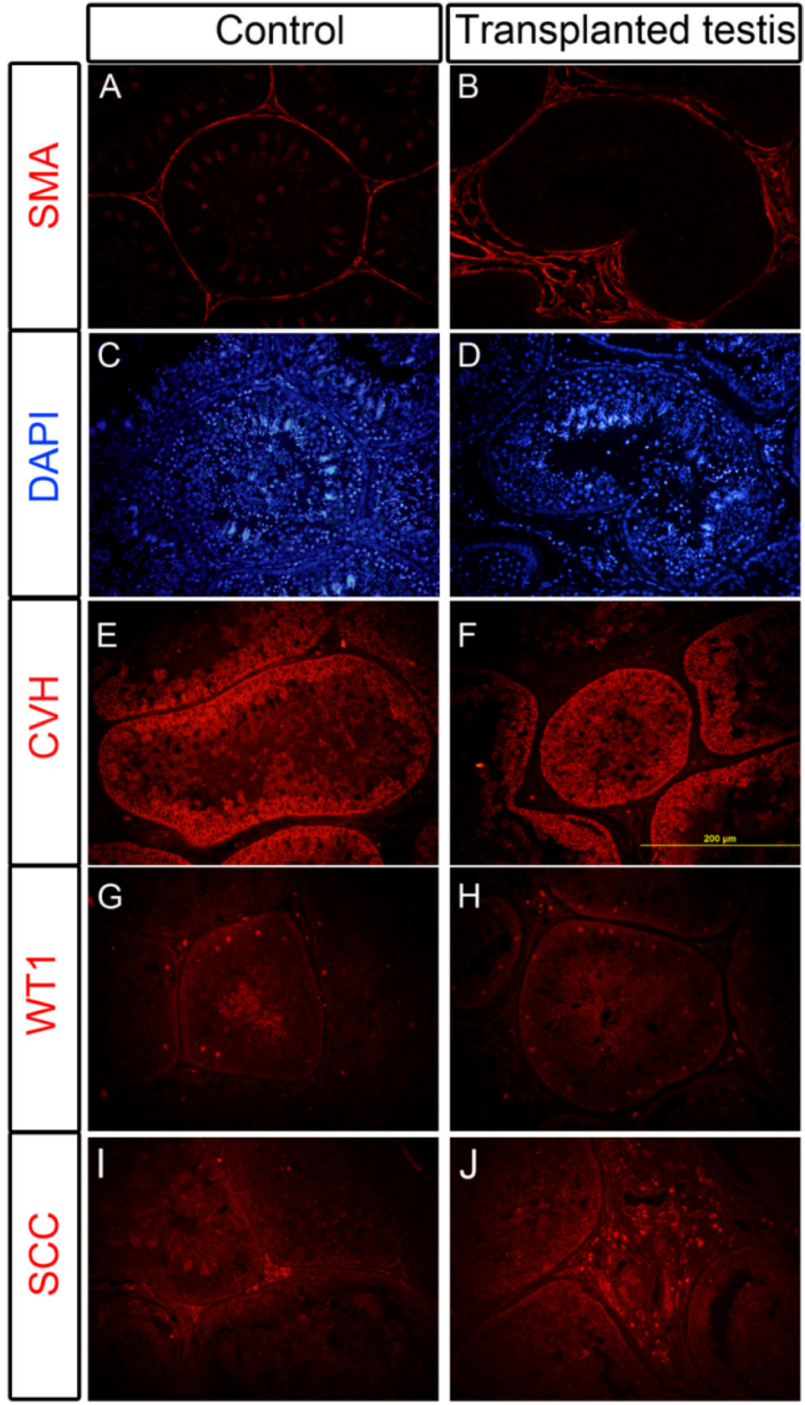

Fig. 3. Auto-transplanted testis tissue can develop seminiferous tubulelike structure and the somatic cells and germ cells have resume their positions after dissociation and re-aggregation $(\mathrm{CVH}$, germ cells; SCC, Leydig cells; WT1, Sertoli cells; SMA, tubule myoid cells).

synthesis. We found that the combs of successfully transplanted chicken grew as large as in control roosters (Fig. 5B, D), but not in those with failed transplantation (Fig. 5E, G). Furthermore, as sufficient testosterone is required for normal spermatogenesis, the ability of the regenerated testicular tissue to produce motile sperm also supported our belief that the Leydig cells were synthesizing testosterone. Therefore, this indicated that 11-week-old immature Leydig cells have not only replenished the interstitial spaces, but also differentiated to maturity, and were able to synthesize testosterone after auto-transplantation.

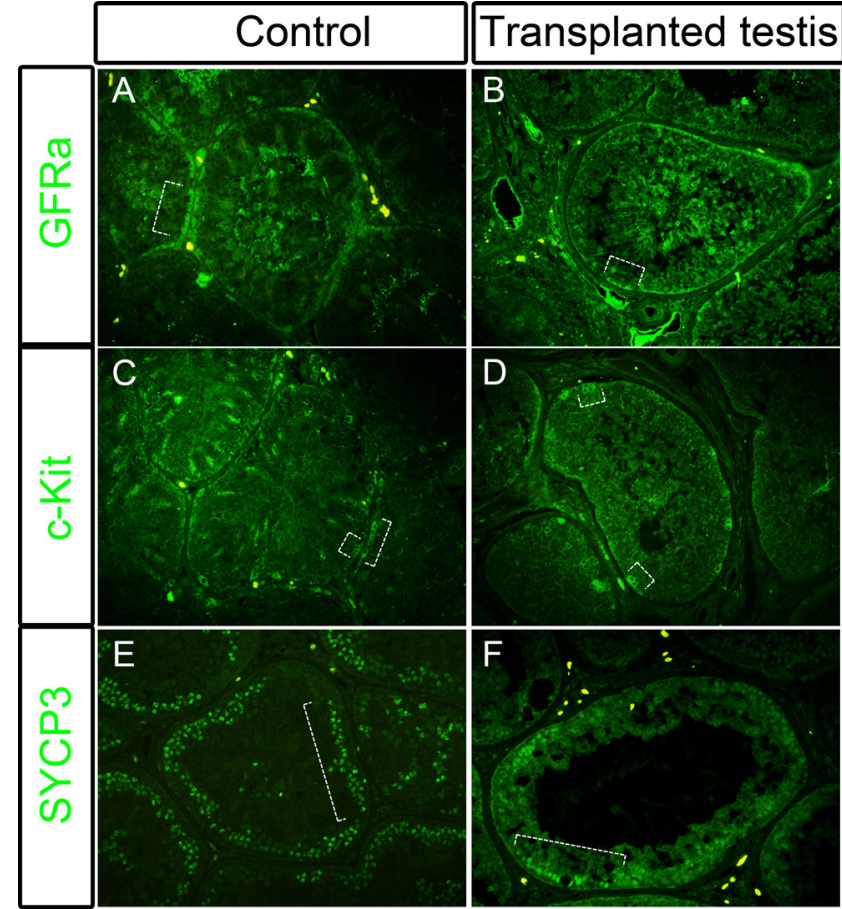

Fig. 4. Auto-transplanted testis tissue contained germ cells of different spermatogenic stages. Chicken spermatogonia in transplanted tissues were active in spermatogenesis as major stages of differentiation, i.e. type $\mathrm{A}_{\text {undiff }}\left(\mathrm{GFR} \alpha 1^{+}\right)$to type $\mathrm{A}_{\text {diff }}\left(\mathrm{c}-\mathrm{kit}^{+}\right)$and finally to meiosis entry $\left(\mathrm{SYCP}^{+}\right)$were observed in comparative manner as in control testes.

\section{Discussion}

Previous studies have demonstrated that chicken testicular tissues may regenerate from tissue blocks, dissociated cells, or tissues after cryopreservation; however, those studies used newly hatched or 2-6- day-old chicks. Here, we have reported that 11-week-old, early-pubertal chicken testes retained the ability to regenerate from a dissociated cell pellet. Our data indicated that the regrowth of transplanted testis was a real regeneration process, as the testicular tissue has the abilities to (1) grow in a compensatory manner, (2) reform testicular structures from the dissociated cells, and (3) regain spermatogenesis and endocrine functions.

As the male White Leghorn chicken reaches sexual maturity after 20 weeks, we collected both our experimental and control samples at this time point. Although the testicular tissues showed a many hundred-fold increase in size, the overall volumes were still smaller than that of the control group testes. In comparison with the report by Song and Silversides (2007) [9], the transplanted testes were able to grow to a similar size as the control and our PCNA analysis revealed that many testicular somatic cells, including Leydig cells and Sertoli cells, were still actively proliferating (Fig. 2), which indicated the capability of continuous growth and the potential to eventually match the size of the control testes.

We used the method of Song and Silversides (2007) [10] and tried testicular slice auto-transplantation on 11-week-old male chickens, 
A
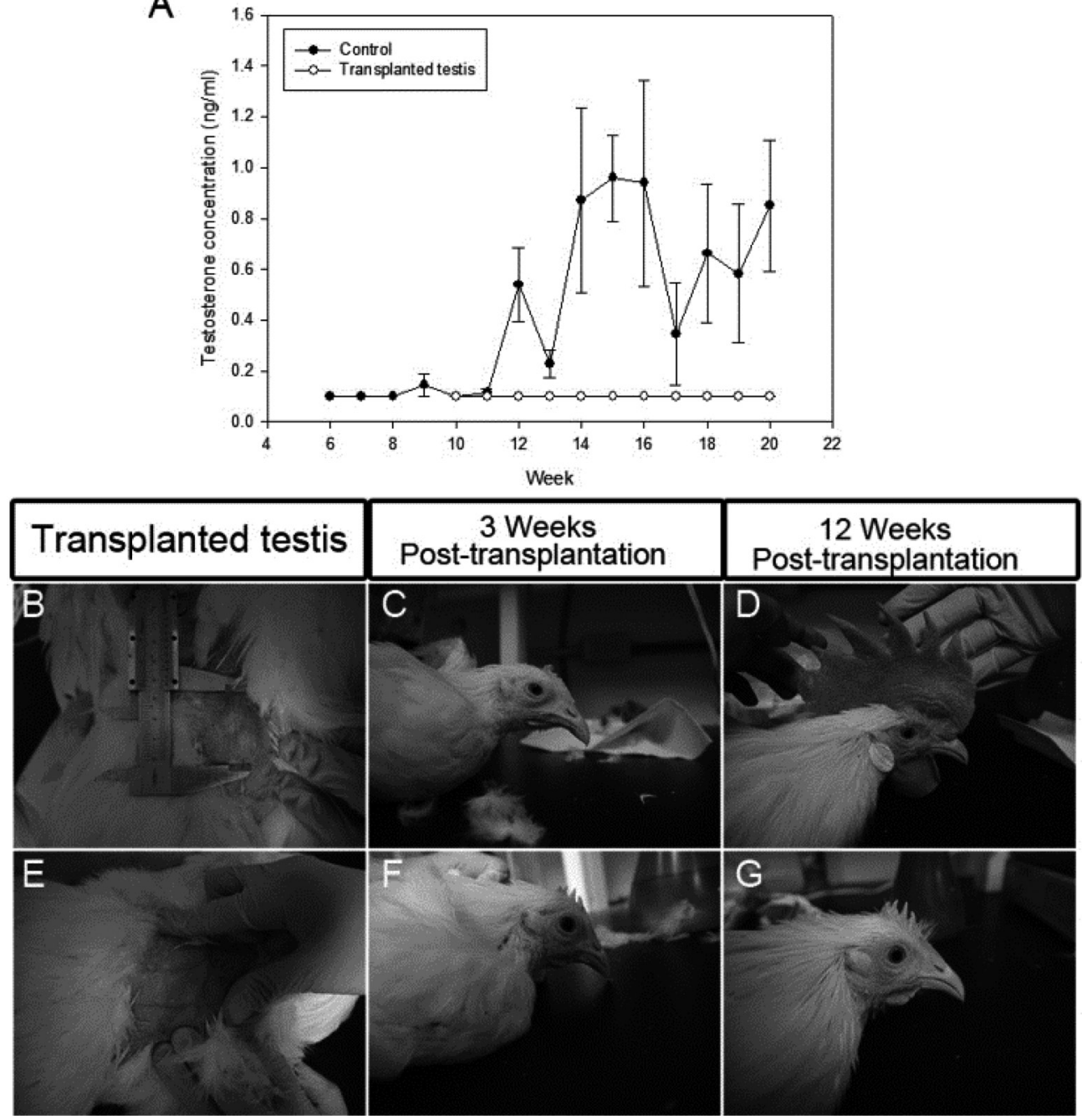

Fig. 5. Functional testosterone production from transplanted testicular tissues. (A) Testosterone concentration was detected with ELISA kit in plasma collected from control roosters, but not from auto-transplanted roosters. The enlarged comb (D) indicated functional testosterone production in testicular tissue auto-transplanted roosters.

and observed that the all the transplanted tissues $(n=3)$ contained few blood cells and resulted in no size increase. The detailed examination of these transplanted tissues revealed that only the peripheral region maintained the tubular structure, whereas the central tissues underwent necrosis (Supplementary Fig. 2: online only).

We observed a much higher success rate of transplantation and regeneration with dissociated cell pellets from the testes of 11-weekold chickens (4/9,44\%), which identified newly formed blood vessels by using histological analysis. The above data may imply that a complete vascular network to fulfil metabolic requirements are necessary for regeneration to occur, and that the dissociated cells have a better angiogenesis induction ability than tissue blocks. Considering the rapidly proliferating status of the 11-week early-pubertal testis, the tissue blocks may have exhausted their resources before a new circulation network can form for nutrient supply. In contrast, the dissociated cells have better access to the host vasculature, which allows the subsequent reorganization and regeneration with neighboring cells. Similar mechanisms were reported; for example, the activation of the VEGF pathway was shown to enhance the vascularization of transplanted testicular grafts and promote testicular regeneration [23].

Our protocol generated dissociated cells and small clusters of between two and ten cells. No intact tubules were found after this procedure (Supplementary Fig. 1: online only). According to the differential adhesion hypothesis, for cell sorting or reorganization to occur in an aggregate, the mixed cells should present different types of cell surface adhesion molecules on their cell membranes [24]. It was reported that the germ cells expressed N-cadherin and E-cadherin, the Sertoli cells expressed N-cadherin, and the Leydig cells expressed P-cadherin $[25,26]$. Therefore, when these dissociated testicular cells were transplanted as mixed aggregates, they should have undergone extensive reorganization to reform the tubular structure and resume their functional positions before rapid proliferation. 
The thermodynamic model suggests that cells that present cadherin proteins with stronger affinity will move to the center [27], whereas cells that expressed cadherin of weaker affinity will be pushed to the outside. Therefore, the different types of cadherin proteins presented on germ cells, Sertoli cells, and Leydig cells would have aided the reorganization, directing Sertoli cells and germ cells into the center, surrounded by Leydig cells. The proper organization and interactions with the neighboring Sertoli cells ensured germ cell differentiation and spermatogenesis [28]. We could not exclude the possibility that some cells may have been mislocated during the reorganization process. For example, Sertoli cells may form a cluster, wrapped by layers of Leydig cells, which blocked the possible inclusion of germ cells. We observed that some tubules contained only Sertoli cells and were devoid of germ cells, which could be caused by the absence of germ cells during the reorganization process, or the loss of germline stem cells owing to lack of proper stem cell maintenance or differentiation factors.

To detect the testosterone synthesized by the regenerating testicular tissues, we used a commercial ELISA kit that was suitable for the detection of testosterone in the control group; however, we did not observe testosterone signals from the roosters in the transplanted group. We suspected that the ELISA kit we used may not be sufficiently sensitive to detect the low level of testosterone synthesized by the regenerating testicular tissues. Although immunoassays are generally believed to be more sensitive than bioassays, testosterone synthesis has its daily rhythm [29] and the immunoassay detection is affected by the time of serum collection. Conversely, the growth of the comb is regulated by the accumulated stimulation of testosterone, despite its daily rhythm. As spermatogenesis is also regulated by testosterone [30], we concluded that the regenerating testicular tissues had synthesized sufficient testosterone to stimulate comb growth and spermatogenesis.

Gonad development is a sophisticated process, regulated by endocrine status, age, and cell differentiation status; previously, the regeneration of testicular tissue has been limited to neonatal mice or newly hatched chicks. This is the first report to successfully demonstrate that the early-pubertal testes also retains the potential for regeneration.

The subcutaneous auto-transplantation in chicken provides a shift of the loci of regeneration from inside the abdomen cavity to body surface, which we think is a better simulation of mammalian testis development. The comparison of the regeneration potential between tissue blocks and dissociated cell pellets suggest that the dissociated cell pellets have a better angiogenic potential that facilitates future regeneration.

The success of early-pubertal testicular regeneration has provided an opportunity to characterize the influences of hormones, aging, and cell differentiation on tissue regeneration, which may allow the development of protocols for the regeneration of adult testes, which have not been previously demonstrated.

\section{Acknowledgments}

This research was supported in part by grant NSC-101-2311B-005-006-MY3 from the National Science Council (currently Ministry of Science and Technology) and by the Ministry of Edu- cation, Taiwan, under the Aiming for Top University plan (ATU104-S0508).

\section{References}

1. Poss KD. Advances in understanding tissue regenerative capacity and mechanisms in animals. Nat Rev Genet 2010; 11: 710-722. [Medline] [CrossRef]

2. Takeo M, Chou WC, Sun Q, Lee W, Rabbani P, Loomis C, Taketo MM, Ito M. Wnt activation in nail epithelium couples nail growth to digit regeneration. Nature 2013; 499: 228-232. [Medline] [CrossRef]

3. Zhao D, McBride D, Nandi S, McQueen HA, McGrew MJ, Hocking PM, Lewis PD, Sang HM, Clinton M. Somatic sex identity is cell autonomous in the chicken. Nature 2010; 464: 237-242. [Medline] [CrossRef]

4. Bowles J, Koopman P. Retinoic acid, meiosis and germ cell fate in mammals. Development 2007; 134: 3401-3411. [Medline] [CrossRef]

5. Herbison AE. Control of puberty onset and fertility by gonadotropin-releasing hormone neurons. Nat Rev Endocrinol 2016; 12: 452-466. [Medline] [CrossRef]

6. Makala H, Pothana L, Sonam S, Malla A, Goel S. Regeneration of Leydig cells in ectopically autografted adult mouse testes. Reproduction 2015; 149: 259-268. [Medline] [CrossRef]

7. Honaramooz A, Megee SO, Rathi R, Dobrinski I. Building a testis: formation of functional testis tissue after transplantation of isolated porcine (Sus scrofa) testis cells. Biol Reprod 2007; 76: 43-47. [Medline] [CrossRef]

8. Kawasaki T, Saito K, Shinya M, Olsen LC, Sakai N. Regeneration of spermatogenesis and production of functional sperm by grafting of testicular cell aggregates in Zebrafish (Danio rerio). Biol Reprod 2010; 83: 533-539. [Medline] [CrossRef]

9. Song Y, Silversides F. Heterotopic transplantation of testes in newly hatched chickens and subsequent production of offspring via intramagnal insemination. Biol Reprod 2007; 76: 598-603. [Medline] [CrossRef]

10. Atesok K, Fu FH, Sekiya I, Stolzing A, Ochi M, Rodeo SA. Stem cells in degenerative orthopaedic pathologies: effects of aging on therapeutic potential. Knee Surg Sports Traumatol Arthrosc 2017; 25: 626-636. [Medline] [CrossRef]

11. Zuba-Surma EK, Wu W, Ratajczak J, Kucia M, Ratajczak MZ. Very small embryonic-like stem cells in adult tissues-potential implications for aging. Mech Ageing Dev 2009; 130: 58-66. [Medline] [CrossRef]

12. Orlu EE, Egbunike GN. Breed and seasonal variations in the testicular morphometry, gonadal and extragonadal sperm reserves of the barred plymouth rock and Nigerian indigenous breeds of the domestic fowl. Pak J Biol Sci 2010; 13: 120-125. [Medline] [CrossRef]

13. Inyawilert W, Liao YJ, Tang PC. Superovulation at a specific stage of the estrous cycle determines the reproductive performance in mice. Reprod Biol 2016; 16: 279-286. [Medline] [CrossRef]

14. Bozkurt HH, Aktaş A, Ulkay MB, Firat UB. Sertoli cell proliferation during the post hatching period in domestic fowl. J Vet Sci 2007; 8: 219-222. [Medline] [CrossRef]

15. Mucksová J, Kalina J, Bakst M, Yan H, Brillard JP, Benešová B, Fafílek B, Hejnar J, Trefil P. Expression of the chicken GDNF family receptor $\alpha-1$ as a marker of spermatogonial stem cells. Anim Reprod Sci 2013; 142: 75-83. [Medline] [CrossRef]

16. Ikami K, Tokue M, Sugimoto R, Noda C, Kobayashi S, Hara K, Yoshida S. Hierarchical differentiation competence in response to retinoic acid ensures stem cell maintenance during mouse spermatogenesis. Development 2015; 142: 1582-1592. [Medline] [CrossRef]

17. Sato T, Aiyama Y, Ishii-Inagaki M, Hara K, Tsunekawa N, Harikae K, Uemura-Kamata M, Shinomura M, Zhu XB, Maeda S, Kuwahara-Otani S, Kudo A, Kawakami H, Kanai-Azuma M, Fujiwara M, Miyamae Y, Yoshida S, Seki M, Kurohmaru M, Kanai Y. Cyclical and patch-like GDNF distribution along the basal surface of Sertoli cells in mouse and hamster testes. PLoS ONE 2011; 6: e28367. [Medline] [CrossRef]

18. Nakagawa T, Sharma M, Nabeshima Y, Braun RE, Yoshida S. Functional hierarchy and reversibility within the murine spermatogenic stem cell compartment. Science 2010; 328: 62-67. [Medline] [CrossRef]

19. Phillips BT, Gassei K, Orwig KE. Spermatogonial stem cell regulation and spermatogenesis. Philos Trans R Soc Lond B Biol Sci 2010; 365: 1663-1678. [Medline] [CrossRef]

20. Hermann BP, Sukhwani M, Hansel MC, Orwig KE. Spermatogonial stem cells in higher primates: are there differences from those in rodents? Reproduction 2010; 139. 479-493. [Medline] [CrossRef]

21. Bowles J, Feng CW, Spiller C, Davidson TL, Jackson A, Koopman P. FGF9 suppresses meiosis and promotes male germ cell fate in mice. Dev Cell 2010; 19: 440-449. [Medline] [CrossRef]

22. Ludwig AW, Boas NF. The effects of testosterone on the connective tissue of the comb of the cockerel. Endocrinology 1950; 46: 291-298. [Medline] [CrossRef]

23. Tian R, Yang S, Zhu Y, Zou S, Li P, Wang J, Zhu Z, Huang Y, He Z, Li Z. VEGF/ 
VEGFR2 signaling regulates germ cell proliferation in vitro and promotes mouse testicular regeneration in vivo. Cells Tissues Organs 2016; 201: 1-13. [Medline] [CrossRef]

24. Steinberg MS, Gilbert SF. Townes and Holtfreter (1955): directed movements and selective adhesion of embryonic amphibian cells. J Exp Zoolog A Comp Exp Biol 2004; 301: 701-706. [Medline] [CrossRef]

25. Newton SC, Blaschuk OW, Millette CF. N-cadherin mediates Sertoli cell-spermatogenic cell adhesion. Dev Dyn 1993; 197: 1-13. [Medline] [CrossRef]

26. Bremmer F, Schweyer S, Marin-Ortega M, Hemmerlein B, Strauss A, Radzun HJ, Behnes CL. Switch of cadherin expression as a diagnostic tool for Leydig cell tumours. APMIS 2013; 121: 976-981. [Medline] [CrossRef]

27. Steinberg MS. Does differential adhesion govern self-assembly processes in histogen- esis? Equilibrium configurations and the emergence of a hierarchy among populations of embryonic cells. J Exp Zool 1970; 173: 395-433. [Medline] [CrossRef]

28. Sugimoto R, Nabeshima Y, Yoshida S. Retinoic acid metabolism links the periodical differentiation of germ cells with the cycle of Sertoli cells in mouse seminiferous epithelium. Mech Dev 2012; 128: 610-624. [Medline] [CrossRef]

29. Bachman SE, Bachman JM, Mashaly MM. Effect of photoperiod on the diurnal rhythm of plasma testosterone, dihydrotestosterone and androstenedione in mature male chickens Comp Biochem Physiol A 1987; 87: 775-779. [Medline] [CrossRef]

30. Wang RS, Yeh S, Tzeng CR, Chang C. Androgen receptor roles in spermatogenesis and fertility: lessons from testicular cell-specific androgen receptor knockout mice. Endocr Rev 2009; 30: 119-132. [Medline] [CrossRef] 